\title{
Long-term Dynamics of the Channel Network in a Glacial Floodplain, Val Roseg, Switzerland*
}

\author{
Rainer Zah, ${ }^{1}$ \\ Markus Niederöst, ${ }^{2}$ \\ Heiko Rinderspacher, ${ }^{3}$ \\ Urs Uehlinger, ${ }^{3}$ and \\ J.V. Ward ${ }^{3}$ \\ 'Department of Ecology, EMPA, \\ Lerchenfeldstr. 5, 9014 St. Gallen, \\ Switzerland. \\ rainer.zah@empa.ch. \\ 2Institute for Geodetics and \\ Photogrammetry, ETH Hönggerberg, \\ 8093 Ziirich, Switzerland. \\ 'Department of Limnology, EAWAG/ \\ ETH, Überlandstr. 133,8600 \\ Dübendorf, Switzerland.
}

\begin{abstract}
The fluvial system in the upper Val Roseg in the Swiss Alps is characterized by a complex glacial floodplain. To analyze the changes in floodplain morphology between 1947 and 1999, a period during which the two main glaciers lost 700 to $1600 \mathrm{~m}$ in length, ten sets of aerial images were rectified and channel network and active floodplain area were digitized into a Geographic Information System (GIS). Changes mainly included an increase in the active floodplain width in the upper part of the floodplain. In the 100 - to $500-\mathrm{m}$ wide floodplain, the average lateral shift of the main channel ranged from 2 to $10 \mathrm{~m} \mathrm{yr}^{-1}$. While the channel network was continuously renewed at a turnover rate of $25 \%$ per year, the overall structure of the Roseg floodplain remained relatively constant, despite rapid glacial retreat that increased the availability of glacial sediments potentially susceptible to fluvial transport. The sinuosity index averaged $1.15 \pm 0.01$ and the braiding index $4.6 \pm 1.2$. Only the connectivity index showed high variation $(6.6 \pm$ 5.0 ), about $34 \%$ of which may be attributed to variation in discharge.
\end{abstract}

\section{Introduction}

Riverine floodplains are spatially complex ecosystems comprising a variety of geomorphic features that include various channel types with different hydrological connectivity (Leopold et al., 1964; Stanford and Ward, 1993; Trockner et al., 1997). Sediment and discharge driven dynamics maintain habitat heterogeneity and connectivity of habitats over the long-term, thus contributing to high levels of species diversity in river floodplains (Ward et al., 1999). Furthermore, fluvial dynamics also control terrestrial floodplain vegetation and, as a consequence, organic matter input to the aquatic system (Zah and Uehlinger, 2001).

Alpine rivers, glacier-fed rivers in particular, are characterized by high sediment yields and extended periods of high discharge. The discharge regime of glacial streams is characterized by low flow between autumn and spring and high flow in summer (Röthlisberger and Lang, 1987). High flow and rainfall induced spates, both usually occurring between August and September when the transient snowline is high (Collins, 1998), can provide substantial amounts of sediments to proglacial rivers. Discharge, sediment supply, and riparian vegetation are presumably the most important factors influencing channel dynamics of proglacial streams (Gurnell et al, 1999). Changes in the cryosphere, for example due to climate change, alter sediment availability and discharge characteristics (Gurnell et al., 1995; Haeberli, 1995; Collins, 1998) with potentially major impacts on habitat richness and species diversity in proglacial river corridors.

In this study, we focused on the long-term dynamics ( 50 yr) of the channel network in an alpine flloodplain below two valley glaciers. On the basis of a set of aerial images, we evaluate channel patterns and turnover rates; both are known to in-

*A version of this paper was presented at the symposium "Highmountain Lakes and Streams: Indicators of a Changing World," 48 September 2000, Innsbruck, Austria. fluence richness and spatial configuration (connectivity) of habitats. Finally, we address possible implications of glacier retreat in the Roseg catchment for floodplain dynamics.

\section{Materials and Methods}

\section{STUDY SITE}

The study system was the Roseg River in the eastern part of the Swiss Alps (Fig. 1). In 1997 about 30\% of the drainage basin (area $66.5 \mathrm{~km}^{2}$ ) was covered by glaciers. Meltwater from the Tschierva and Roseg glaciers is the primary water source of the Roseg River. The Roseg Glacier ends in a lake that has existed since 1940 and interrupts the transport of coarse sediments from the glaciated Roseg basin to the main floodplain. The floodplain is about $2800 \mathrm{~m}$ long and 100 to $500 \mathrm{~m}$ wide with elevations ranging from 1995 to $2100 \mathrm{~m}$ a.s.l. Sediments consist exclusively of crystalline (mainly granitic) rocks (Malard et al., 1999) with a median $b$-axis of $9.3 \mathrm{~cm}$ in the proglacial reach and a median $b$-axis of $7.5 \mathrm{~cm}$ in the floodplain reach. Within the floodplain, different channels types can be distinguished based on their hydrological connectivity and physicochemical attributes (Tockner et al., 1997). Channel types include the main channel, that carries more than $70 \%$ of the meltwater from the two valley glaciers, side channels of the main channel, channels intermittently connected upstream to the main channel, groundwater channels with no upstream connection to the main channel, and side-slope tributaries.

\section{SURVEY AND IMAGE ANALYSES}

Aerial photographs (color film and color infrared film) of the Val Roseg floodplain were taken on 29 July 1998, at 13:00 GMT with a standard aerial camera (WILD 21 NAGIIA-F, focal length $214.74 \mathrm{~mm}$ ). Color film was used for the generation of a digital elevation model (DEM), while orthophotos were created from color infrared images for a better differentiation of vege- 


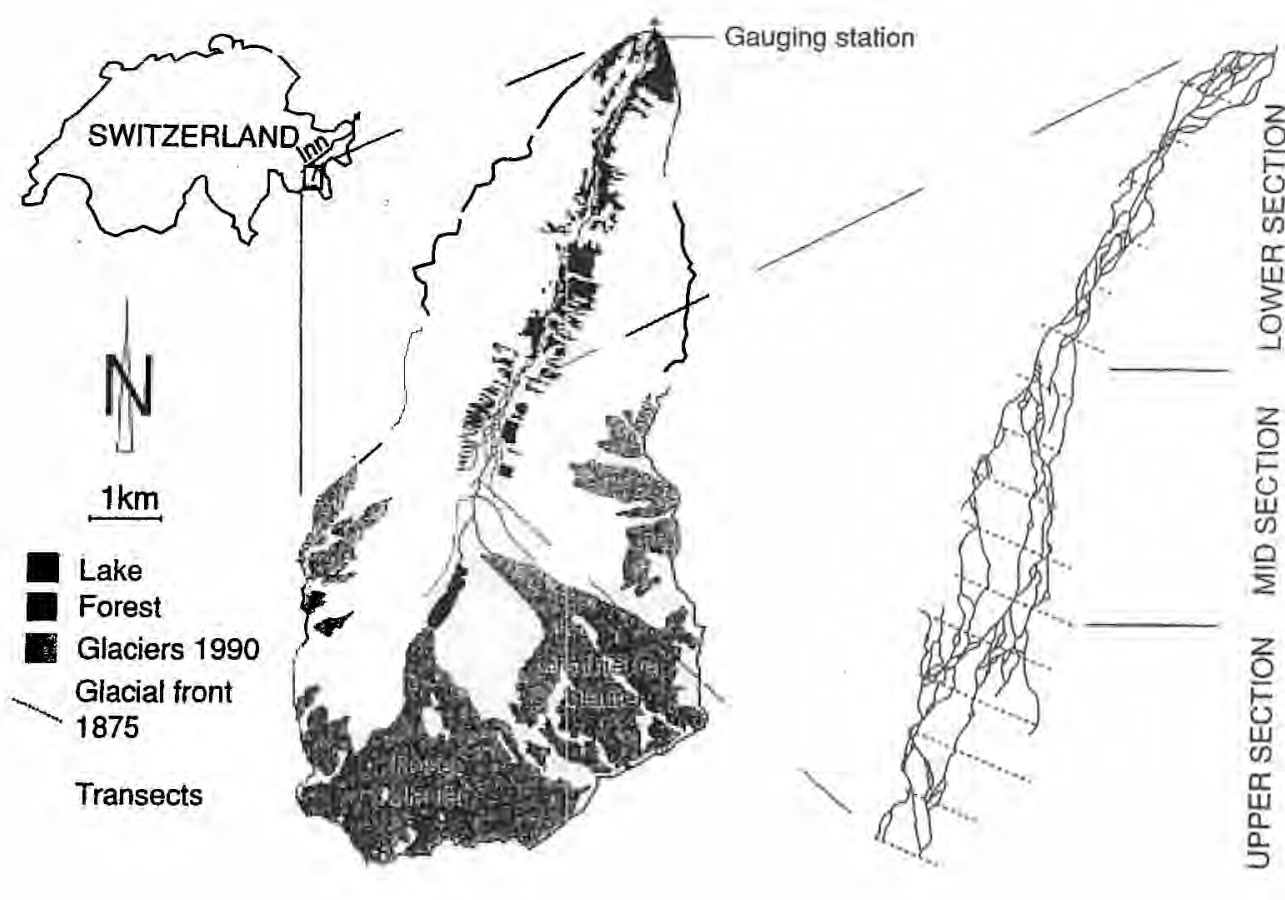

FIGURE 1. Val Roseg catchment with glacier area of 1990 and detail map of the floodplain. tation patterns and areas covered by water. Two low-elevation image strips covering the whole floodplain area were scanned (scale 1:5000, scan resolution 21 microns). The exterior orientation of the images was determined in a bundle block adjustment for each strip separately using ground control points that were measured with differential GPS and marked prior to the flight. The photogrammetric evaluation was completed with the digital station PHODIS (by ZI-Imaging). The data provided for the analysis with GIS consisted of a DEM with a raster width of $2 \mathrm{~m}$ for the floodplain (estimated height accuracy about 0.12 m). Digital color infrared orthophotos of the floodplain were created with a footprint of $0.25 \mathrm{~m}$.

The high-accuracy DEM and color-IR-orthophotos then were used for the spatial correction of six sets of black-and-white aerial images (1947 partially, 1955, 1971, 1979, 1985, 1991; resolution: $1 \mathrm{~m}$ ), two sets of color-images shot from helicopter (1996, 1997; resolution: $0.5 \mathrm{~m}$ ), and an additional set of colorIR images (1999; resolution: $0.25 \mathrm{~m}$ ) (Table 1). All of these spatial corrections were performed using OrthoEngine (by PCIGeomatics) on an UNIX-workstation. The time of day and date of the aerial surveys are shown in Table 1. The time interval between 11:00 h and 12:00 h is close to the end of the daily flow minimum. Discharge varied between the surveys ( 2 to 11 $\mathrm{m}^{3} \mathrm{~s}^{-1}$ ) due to different meteorological conditions.

Using ArcInfo (ESRI, 1994) as the GIS-application, the flow paths of the active channels and the border of the active floodplain were digitized as line coverages for each of the 10 sampling dates. Further analyses were performed using only these coverages.

\section{STRUCTURE AND DYNAMICS OF THE CHANNEL NETWORK}

Braiding index and sinuosity index were calculated for each sampling date as described by Friend and Sinha (1993). $L_{\text {cto }}$ represents the total channel length of the main channel and the side channels, whereas $L_{c \max }$ is the length of the thalweg. $L_{r}$ the length of the reach, expresses the north-south expansion of the braided floodplain. The connectivity index indicates the ratio of channels with an upstream connection to the main channel
$\left(L_{\text {up.comn }}\right)$ to channels that are only downstream connected or completely abandoned from the main channel ( $\left.L_{\text {no.conn }}\right)$.

$$
\begin{gathered}
\text { braiding index }=L_{c \text { cor }} / L_{c \text { max }} \\
\text { sinuosity index }=L_{c \operatorname{cmax}} / L_{r} \\
\text { connectivity index }=L_{\text {up.comn }} / L_{\text {no.conn }}
\end{gathered}
$$

Determination of channel turnover was based on comparisons of subsequent sets of channel coverages. Persistent channels were marked manually and turnover was calculated as channel loss during the interval $\left(t_{i}, t_{i+1}\right)$ divided by the number of channels at time $t_{i}$ multiplied by 100 . Lateral shift of the main channel was measured for each pair of aerial images across 14 transects along the floodplain (distance between transects ranged from 150 to $200 \mathrm{~m}$, Fig. 1). The active floodplain border was defined as the border between gravel bars and persistent vegetation cover. Active floodplain width then was determined for each of the 14 transects.

\section{DISCHARGE AND CHANGE IN GLACIER LENGTH}

Discharge records (mean daily discharge) were available from a gauging station at the lower end of the Roseg catchment (Fig. 1). The record started in spring 1954. To explore changes in flow during the 52-yr period, we used mean annual discharge and the number days per year when mean daily discharge exceeded $10,12.5$, and $15 \mathrm{~m}^{3} \mathrm{~s}^{-1}$. Annual data of length changes of Tschierva and Roseg glaciers since 1900 were provided by the World Glacier Monitoring Service (e.g., Haeberli et al., 1998). The area of newly available sediments due to glacial retreat of the Tschierva Glacier was assessed for different time periods by analyzing the available aerial images. Aerial images of the Roseg Glacier were not analyzed, because this glacier ends in a lake that disrupts sediment transport to the riverine system.

\section{Results}

The lengths of Tschierva and Roseg glaciers decreased from 1947. to 1999 by $700 \mathrm{~m}$ and $1570 \mathrm{~m}$, respectively (Fig. 2A), in 

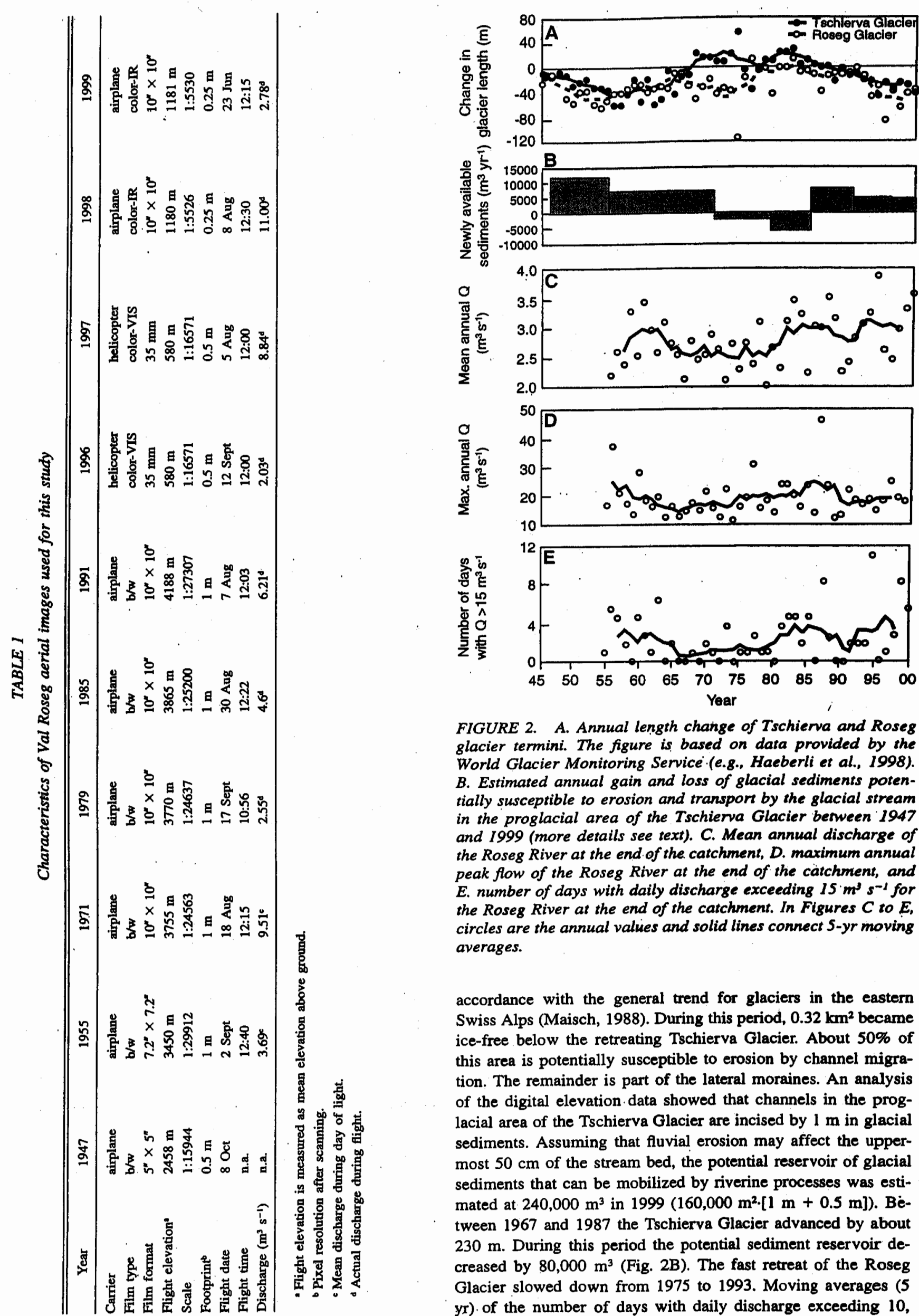

FIGURE 2. A. Annual length change of Tschierva and Roseg glacier termini. The figure is based on data provided by the World Glacier Monitoring Service (e.g., Haeberli et al., 1998). $B$. Estimated annual gain and loss of glacial sediments potentially susceptible to erosion and transport by the glacial stream in the proglacial area of the Tschierva Glacier benveen 1947 and 1999 (more details see text). C. Mean annual discharge of the Roseg River at the end of the catchment, D. maximum annual peak flow of the Roseg River at the end of the catchment, and $E$. number of days with daily discharge exceeding $15 \mathrm{~m}^{3} \mathrm{~s}^{-1}$ for the Roseg River at the end of the catchment. In Figures $C$ to $E$, circles are the annual values and solid lines connect 5-yr moving averages.

accordance with the general trend for glaciers in the eastern Swiss Alps (Maisch, 1988). During this period, $0.32 \mathrm{~km}^{2}$ became ice-free below the retreating Tschierva Glacier. About 50\% of this area is potentially susceptible to erosion by channel migration. The remainder is part of the lateral moraines. An analysis of the digital elevation data showed that channels in the proglacial area of the Tschierva Glacier are incised by $1 \mathrm{~m}$ in glacial sediments. Assuming that fluvial erosion may affect the uppermost $50 \mathrm{~cm}$ of the stream bed, the potential reservoir of glacial sediments that can be mobilized by riverine processes was estimated at $240,000 \mathrm{~m}^{3}$ in $1999\left(160,000 \mathrm{~m}^{2} \cdot[1 \mathrm{~m}+0.5 \mathrm{~m}]\right)$. Bétween 1967 and 1987 the Tschierva Glacier advanced by about $230 \mathrm{~m}$. During this period the potential sediment reservoir decreased by $80,000 \mathrm{~m}^{3}$ (Fig. 2B). The fast retreat of the Roseg Glacier slowed down from 1975 to 1993 . Moving averages (5 $\mathrm{yr})$. of the number of days with daily discharge exceeding 10 , 

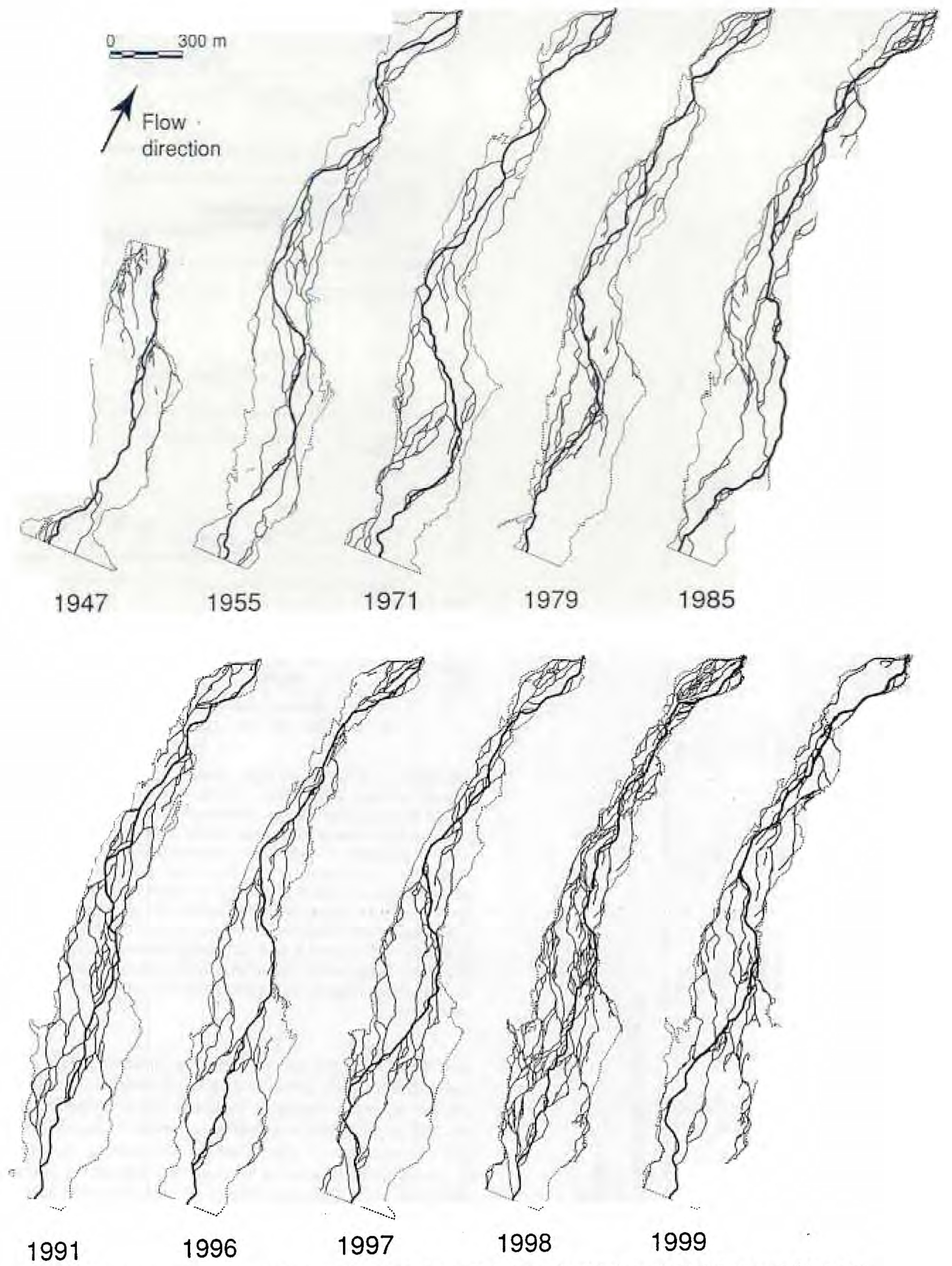

FIGURE 3. Development of channel network in the Val Roseg floodplain as derived from aerial images; bold line indicates thalweg of the main channel, fine dotted line delimits the active floodplain. 


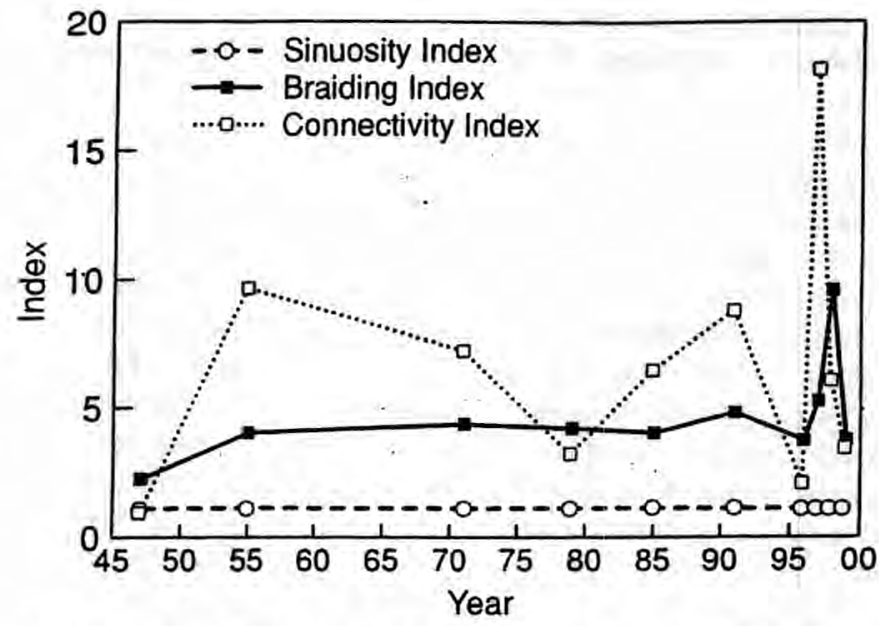

FIGURE 4. Sinuosity, braiding index, and connectivity index during aerial surveys between 1947 and 1999.

12.5 , and $15 \mathrm{~m}^{3} \mathrm{~s}^{-1}$ of mean annual discharge significantly increased since 1955 with time (regression analysis, $N_{Q>10}: R^{2}=$ $0.28, P<0.001, N_{Q>12.5}: R^{2}=0.34, P<0.001, N_{Q>15}: R^{2}=$ $0.20, P<0.01, Q_{\text {mean }}: R^{2}=0.26, P<0.001$, Fig. 2 C, E)..Maximum annual discharge showed no consistent temporal pattern $(P=0.40$, Fig. 2D).

Figure 3 depicts the development of the channel network and the active floodplain area over the past 52 yr. Many channels, especially groundwater channels, do not migrate during long time periods. The high channel density in 1998 coincided with exceptionally high discharge $\left(11 \mathrm{~m}^{3} \mathrm{~s}^{-1}\right)$ during the aerial survey. The width of the active floodplain continuously increased in the upper floodplain over the past $52 \mathrm{yr}$. The active floodplain width remained constant in the middle section. A reduction in active floodplain width in the lower section was observed during the last $10 \mathrm{yr}$ due to dams built from sediments to protect adjacent pastureland. Overall, the active floodplain area increased by $10.3 \%$ between 1955 and 1999. Figure 4 shows the temporal development of three morphological indexes. The sinuosity index of the Roseg River remained constant (1.15 \pm $0.01)$. The braiding index varied only slightly $(4.6 \pm 1.2)$, being almost constant up to a discharge of $10 \mathrm{~m}^{3} \mathrm{~s}^{-1}$. The connectivity index, in contrast, showed high variation $(6.6 \pm 5.0)$, about $34 \%$ of which may be attributed to variation in discharge (regression analysis $P<0.05$ ).

The main channel shifted almost over the entire floodplain, but highest shift rates were measured in the upper section (Fig. 5). This lateral movement varied distinctly between subsequent observation periods ( 20 to $100 \mathrm{~m}$ ). Channel turnover calculated for various time periods increased from $30 \%$ (1-yr interval) to $70 \%$ for time periods $>20 \mathrm{yr}$ (Fig. 6 ). About $50 \%$ of the channel network was subject to change within a $10-$ yr period but many former channels that persisted over time periods of $>20 \mathrm{yr}$ were only temporarily disconnected. This may explain why channel turnover did not exceed $70 \%$. The resulting equation from Figure 6 was used to calculate annual turnover for the different observation periods (Fig. 7). The first period (1947-55) showed a high annual turnover of $40 \%$ (however, the 1947 aerial survey covered only the dynamic upper floodplain), while annual turnover ranged from 20 to $30 \%$ after 1955 .

In the floodplain, channel dynamics created a dynamic patch mosaic of different terrestrial vegetation. Bare gravel or gravel with initial stages of pioneer plant communities prevailed in about $70 \%$ of the active floodplain area. In areas not affected

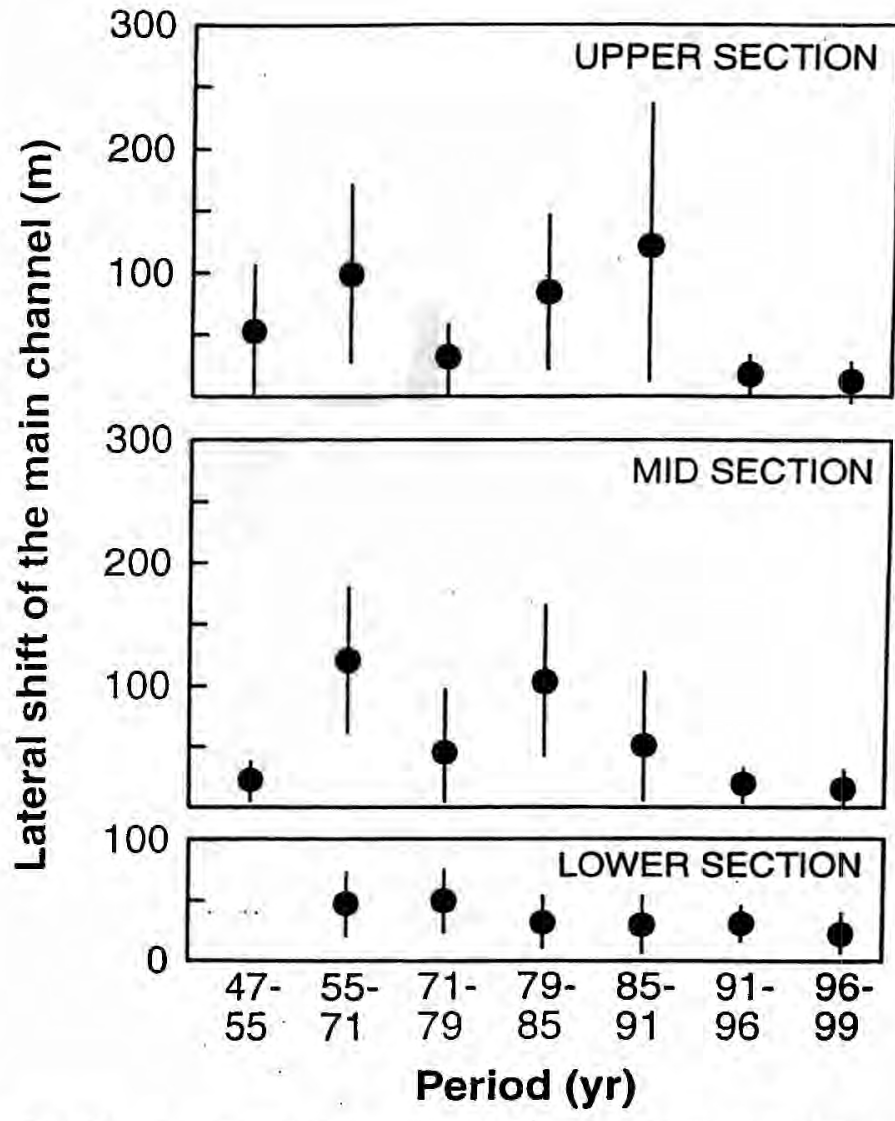

FIGURE 5. Lateral shift of the main channel (thalweg) between aerial surveys. Average (filled circle) and standard deviation (bar). The number of transects is 5 in the upper section, 5 in the mid section, and 7 in the lower section. Time intervals range from 3 to $16 \mathrm{yr}$.

by channel migration for more than $30 \mathrm{yr}$, dense grassland with few scattered shrubs but no trees can be found. Coniferous forests dominated by Larix decidua, Pinus cembra, and Pinus mugo were restricted to valley slopes.

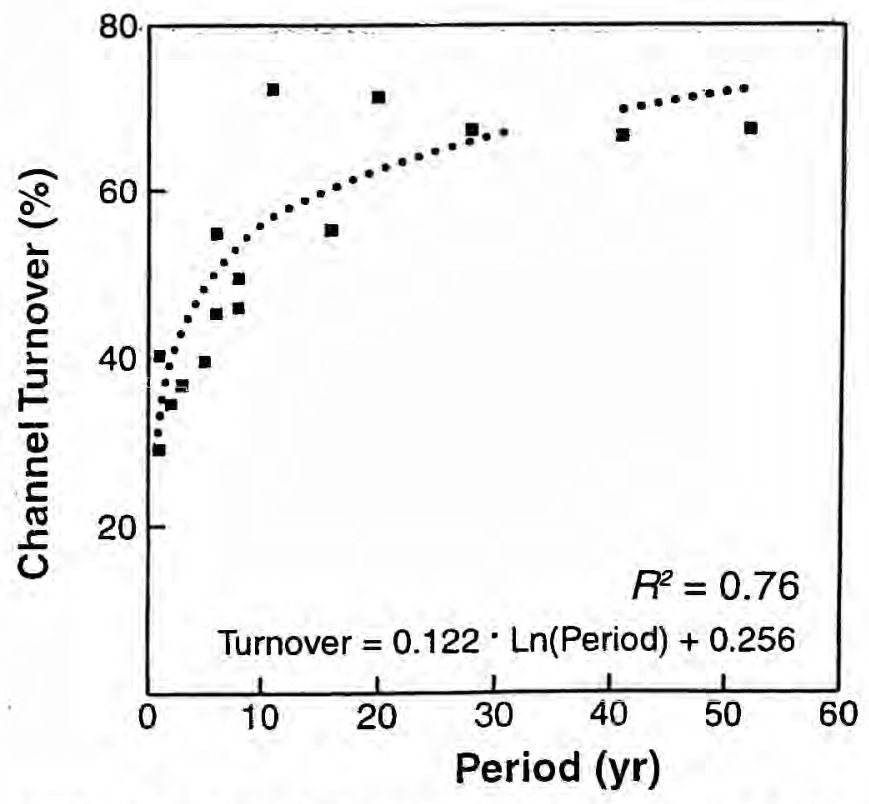

FIGURE 6. Channel turnover in relation to the length of periods between surveys. 


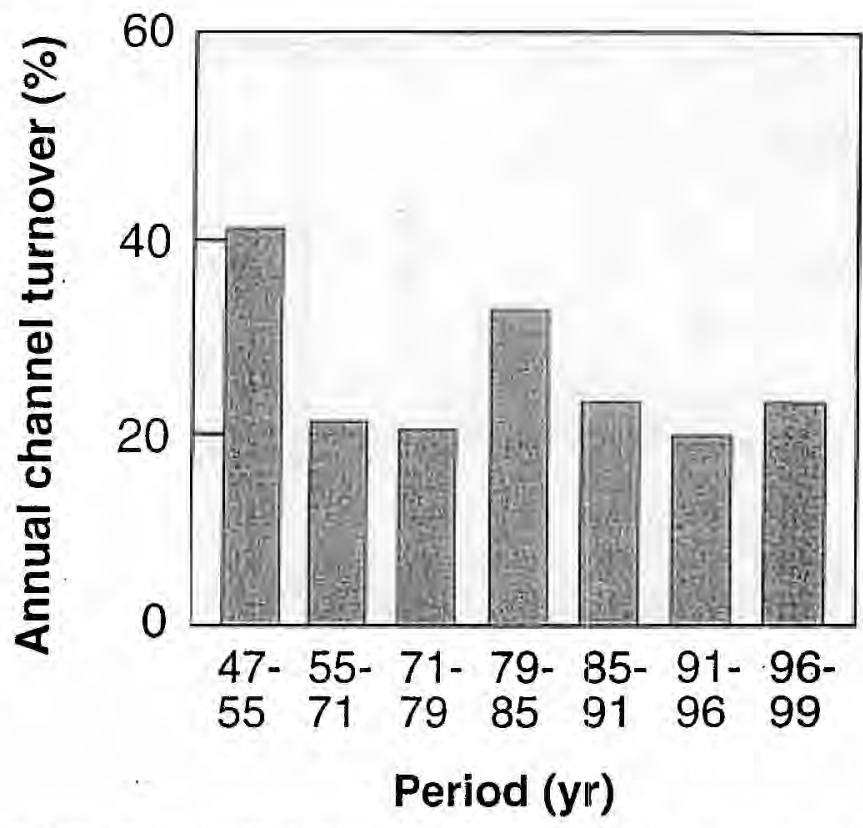

FIGURE 7. Estimated average annual channel turnover between subsequent aerial surveys. The period 1947 to 1955 only includes channel turnover in the upper half of the floodplain.

Regression analysis indicated no relationship between length change of the two glaciers and main channel turnover, main channel shift, or other measured morphological parameters (Table 2). There also was no correlation between mean annual discharge or days with daily discharge exceeding 10,12.5, and $15 \mathrm{~m}^{3} \mathrm{~s}^{-1}$ and any of the morphological variables. Only the annual maximum peak flow correlated significantly with the braiding and connectivity indexes.

\section{Discussion}

This study is mainly based on aerial images. Image quality and environmental conditions during the survey, however, may affect the evaluation of data. Our source images were different in terms of resolution and color bands (Table 1). The spatial correction of the aerial images resulted in horizontal position errors of $<5 \mathrm{~m}$ for $95 \%$ of the pixels and an additional error $<5$ m was introduced by manually digitizing the channel network. The estimated total error is $<7 \mathrm{~m}$. This precision is adequate for digitizing flow paths of 2- to 15-m-wide channels but not for digitizing corresponding channel areas. Apart from image quality, the evaluation of the channel network may be affected by different discharges during subsequent aerial surveys. Sinuosity seemed to be rather independent of discharge (Fig. 4) and the braiding index remained constant unless discharge exceeded 9.5 $\mathrm{m}^{3} \mathrm{~s}^{-1}$. Connectivity showed high variation, $34 \%$ of which may be explained by discharge. We are, however, aware that several aerial surveys covering different discharge situations within a short period ( $\leq 1 \mathrm{mo}$, no major floods) would be necessary to properly evaluate the influence of discharge.

The active floodplain is relatively large in relation to the current flow regime. Disconnection and reconnection of former channels (many of the channels persist for more than $30 \mathrm{yr}$ ) to the main channel in the upper floodplain section induce the major changes in the channel network. However, turnover rates were relatively low ( $25 \%$ mean annual turnover). For example, in the low-elevation floodplain of the Tagliamento River with gravel as the dominating substratum, more than $50 \%$ of the channel network can be renewed within one year due to sheet flow (Kollmann et al., 1999). Sheet flow is lacking in the Roseg floodplain where channel erosion and aggradation mainly occur along the main channel (average annual lateral shift 2 to $10 \mathrm{~m} \mathrm{yr}^{-1}$ ), leading to major channel reconnections every 15 to $25 \mathrm{yr}$ (Fig. 3). The relatively slow but continuous habitat renewal results in a persistent dynamic pattern of various habitats (Malard et al., 2000), which partly accounts for the diverse invertebrate community in the harsh proglacial environment (Burgherr and Ward, 2001).

This study comprises a unique data set documenting changes in the channel network of a glacial floodplain over more than 50 yr. Substantial glacier retreat and a relatively persistent morphological configuration of the glacial floodplain characterize this period. The retreating Tschierva Glacier exposed substantial amounts of sediments susceptible to fluvial erosion. Regression analyses showed that the number of days with daily discharge exceeding $10,12.5$, or $15 \mathrm{~m}^{3} \mathrm{~s}^{-1}$ slightly increased during the past $45 \mathrm{yr}$; we lack reliable information whether this increase enhanced the transport of sediments to the floodplain. The growing active floodplain area, particularly in the upper part, may be explained by higher transport capacity and sediment availability. Linking long-term floodplain evolution to glacial retreat requires consideration of sediment transport processes, which are determined by discharge and channel morphology (Lane et al., 1996; Lane and Richards, 1997). However, this requires data on sediment transport and information on morphological changes at higher temporal and spatial resolution than examined here. Gurnell et al. (1999) developed a conceptual model that describes scenarios of alpine proglacial river evolution under changing climate conditions. Their model predicts actively braiding proglacial river systems below rapidly retreating glaciers if proglacial. zones are close to the treeline, and that under these conditions floodplain development is controlled by the sediment regime rather than by riparian vegetation. The Roseg floodplain appears to fit into this framework. In relation to the lateral shift of the main channel, the growth of woody vegetation was apparently

TABLE 2

Linear regressions of mean discharge $\left(Q_{\text {mean }}\right)$, maximum peak flow $\left(Q_{\text {max }}\right)$, periods with discharge $>15 m^{3} s^{-1}$, and change in glacier length $v s$. changes in floodplain parameters. Indicated are $\mathrm{R}^{2}$ and $\mathrm{P}$-values

\begin{tabular}{|c|c|c|c|c|c|c|c|c|}
\hline \multirow{2}{*}{$\begin{array}{l}\text { Floodplain } \\
\text { parameters }\end{array}$} & \multicolumn{2}{|c|}{$Q_{\text {mean }}$} & \multicolumn{2}{|c|}{$Q_{\text {mas }}$} & \multicolumn{2}{|c|}{$Q>15 \mathrm{~m}^{3} \mathrm{~s}^{-1}$} & \multicolumn{2}{|c|}{ Glacier length } \\
\hline & $R^{2}$ & $P$ & $R^{2}$ & $P$ & $R^{2}$ & $P$ & $R^{2}$ & $P$ \\
\hline Braiding index & 0.12 & 0.50 & 0.85 & $<0.01$ & 0.07 & 0.61 & 0.20 & 0.32 \\
\hline Connectivity index & 0.00 & 0.92 & 0.64 & $<0.05$ & 0.00 & 0.92 & 0.02 & 0.77 \\
\hline Channel turnover & 0.39 & 0.19 & 0.46 & 0.09 & 0.20 & 0.37 & 0.21 & 0.30 \\
\hline Main channel shift & 0.28 & 0.29 & 0.01 & 0.85 & 0.31 & 0.25 & 0.05 & 0.65 \\
\hline Active floodplain area & 0.01 & 0.85 & 0.25 & 0.25 & 0.00 & 0.94 & 0.02 & 0.73 \\
\hline
\end{tabular}


too slow (because of high altitude) to stabilize channel margins. However, riparian succession also may be constrained by cattle grazing that takes place every year for about two weeks in late spring and late summer.

In summary, structure and turnover rate of the channel network were surprisingly constant during the 52-yr observation period. The only parameter that showed a persistent change was the active floodplain width that continuously increased, particularly in the upper section. Factors limiting change in floodplain morphology are presumably the low magnitude and frequency of high flow periods and spates rather than sediment availability. Recent studies on the effects of climate change in the Alps predict an increase of hydrologic extremes such as floods (Wanner et al., 1997; Imboden, 1998). Because of the large sediment storage in the proglacial area of the Tschierva Glacier, we anticipate an increase in floodplain dynamics in the Val Roseg if current climate trends continue.

\section{Acknowledgments}

We wish to thank Schweizer Landestopographie for access to archived aerial images and the Koordinationsstelle für Luftaufnahmen (KSL) for photographing the color-IR aerial images. Many thanks go to Philippe Meuret from the Remote Sensing Lab (RSL) of the Geography Department, University of Zurich, for introducing us to the world of photogrammetry. We also thank F. Malard and C. T. Robinson for fruitful scientific discussions and comments on this manuscript. The Swiss National Hydrological and Geological Survey kindly provided discharge data of the Roseg River. This study was supported by a research grant from Swiss National Science Foundation (SNF 2149243.96).

\section{References Cited}

Burgher,, P. and Ward, J. V., 2001: Longitudinal and seasonal distribution patterns of the benthic fauna of an alpine glacial stream (Val Roseg, Swiss Alps). Freshwater Biology, in press.

Collins, D. N., 1998: Outburst and rainfall-induced peak runoff events in highly glacierized Alpine basins. Hydrological Processes, 12: 2369-2381.

ESRI, 1994: ARC Commands. Environmental Systems Research Institute, Redlands, California.

Friend, P. F. and Sinha, R., 1993: Braiding and meandring parameters. In Best, J. L. and Bristow, C. S. (eds.), Braided Rivers. London: Geological Society Special Publication, 105111.

Gurnell, A. M., Edwards, P. J., Petts, G. E., and Ward, J. V., 1999: A conceptual model for alpine proglacial river channel evolution under changing climatic conditions. Catena, 38: 223-242.

Gurnell, A. M., Simmons, D., and Edwards, P. J., 1995: Integrating river corridor environment information through multivariate ecological analysis and geographic information systems. In Harper, D. M. and Ferguson, A. J. D. (eds.), The Ecological Basis for River Management. Chichester: Wiley, 251-268.
Haeberli, W., 1995: Climate change impacts on glaciers and permafrost. In Guisan, A., Holten, J. I., Spichiger, R., and Tessier, L. (eds.), Potential Ecological Impacts of Climate Change in the Alps and Fennoscandian Mountains. Geneva, Switzerland: Conservatoire et Jardin botaniques de la Ville de Genève, 97103.

Haeberli, W., Hoelzle, M., Suter, S., and Frauenfelder, R., 1998: Fluctuations of Glaciers 1990-1995 compiled by the World Glacier Monitoring Service. IAHS (ICSI)-UNEPUNESCO, Paris.

Imboden, D. M., 1998: Views from the Alps-Regional perspectives on climate change-Introduction. In Cebon, P., Dahinden, U., Davies, H., Imboden, D. M., and Jaeger, C. C. (eds.), Views From The Alps. Cambridge: MTT Press, 1-20.

Kollmann, J., Vieli, M., Edwards, P. J., Tockner, K., and Ward, J. V., 1999: Interactions between vegetation development and island formation in the Alpine river Tagliamento. Applied Vegetation Science, 2: 25-36.

Lane, S. N. and Richards, K. S., 1997: Linking river channel form and process: Time, space and causality revisited. Earth Surface Processes and Landforms, 22: 249-260.

Lane, S. N., Richards, K. S., and Chandler J. H., 1996: Discharge and sediment supply controls erosion and deposition in a dynamic alluvial channel. Geomorphology, 15: 1-15.

Leopold, L. B., Wolman, M. G., and Miller, J. P., 1964: Fluvial Processes in Geomorphology. San Francisco: Freeman, 522 pp.

Maisch, M., 1988: Die Veränderungen der Gletscherflächen und Schneegrenzen seit dem Hochstand von 1850 im Kanton Graubünden (Schweiz). Zeitschrift für Geomorphorphologie, 70: 113-130.

Malard, F., Tockner, K., and Ward, J. V., 1999: Shifting Dominance of Subcatchment Water Sources and Flow Paths in a Glacial Floodplain, Val Roseg, Switzerland. Arctic, Antarctic, and Alpine Research, 31: 135-150.

Malard, F, Tockner, K., and Ward, J. V., 2000: Physico-chemical heterogeneity in a glacial riverscape. Landscape Ecology, 15: 679-695.

Röthlisberger, H. and Lang, H., 1987: Glacial Hydrology. In Gurnell, A. M. and Clark, M. J. (eds.), Glacio-fluvial Sediment Transfer. Chichester: Wiley, 207-284.

Stanford, J. A. and Ward, J. V., 1993: An ecosystem perspective of alluvial rivers: connectivity and the hyporheic corridor. Journal of the North American Benthological Society, 12: 4860.

Tockner, K., Malard, F., Burgherr, P., Robinson, C. T., Uehlinger, U., Zah, R., and Ward, J. V., 1997: Physico-chemical characterization of channel types in a glacial ecosystem (Val Roseg. Switzerland). Archiv für Hydrobiologie, 140: 433-463.

Wanner, H., Rickli, R., Salvisberg, E., Schmutz, C., and Schuepp, M., 1997: Global climate change and variability and its infuence on Alpine climate-Concepts and observations. Theoretical and Applied Climatology, 58: 221-243.

Ward, J. V., Tockner, K., and Schiemer, F., 1999: Biodiversity of floodplain river ecosystems: ecotones and connectivity. Regulated Rivers: Research and Management, 15: 125-139.

Zah, R. and Uehlinger, U., 2001: Particulate organic matter inputs to a glacial stream system in the Swiss Alps. Freshwater Biology, in press. 